\title{
William Alexander Robertson, P.F.A., F.C.I.I.
}

THE sudden death of William Alexander Robertson, President of the Faculty of Actuaries, on April 4, 1940, whilst on a business visit to London, came as a shock not only to the insurance world but also to a much wider circle.

Educated at George Watson's College, which he left in I 894 to enter the insurance profession, he commenced his career at the Head Office of the Scottish Metropolitan Insurance Company. A few years later he joined the Scottish Union and National Insurance Company. $\mathrm{He}$ entered the service of the Century Insurance Company Limited in I908 as Actuary. Later he became Assistant Manager and Actuary and afterwards Manager and Actuary. This position he held at the date of his death.

He was a dynamic personality. He endeared himself to all with whom he came in contact by his enthusiasm about everything he took in hand. Much of his time he devoted to assisting in their studies the young men in the insurance business. For many years he was an outstanding tutor of Actuarial Science and for a time acted as Lecturer on this subject at the University of Edinburgh. He contributed many papers to insurance societies all over the country. Actuarial Theory, of which he was joint author, has been of inestimable value to actuarial students throughout the world. $\mathrm{He}$ was a leading authority on sickness and disability insurance and his contributions on these subjects have enhanced insurance literature. He was a former President of the Insurance Society of Edinburgh and a former President of the Watsonian Club. He did much for the senior boys of George Watson's College.

He was an enthusiast for Rugby football. He strongly advocated its value in developing character, sportsmanship and what he called the "team spirit." During thirty years of active refereeing he handled' many important games, including the International matches between England and France at Twickenham in 1919 and between Ireland and England at Dublin in 1920. Not infrequently he refused an important senior match so that he might referee school games and afterwards lecture to the boys on the intricacies and spirit of the game. He gave valuable service in organising the annual seven-a-side tournaments in aid of the Edinburgh Royal Infirmary.

William Alexander Robertson by his enthusiasm, energy and thoroughness set a very high example, and he had that rare quality of bringing out the best in all with whom he came in contact.

He was elected a Fellow in I9I9.

A. G. R. B. 